\title{
Empire of the Young: The Legacies of State Agricultural Policy on Local Capitalism and Social Support Networks in Ghana and Côte d'Ivoire
}

\author{
LAUREN MORRIS MACLEAN \\ University of Michigan \\ INTRODUCTION
}

While most American academics and policymakers are familiar with the problems facing the growing elderly population in the United States, many are surprised to learn of the troubles confronting the aged in Africa. In stark contrast to the mythic image of the tightly-knit extended family, where grandparents are lovingly cared for as a respected and integral part of the family unit, is the unforgiving reality of hunger, ill health, and loneliness that is the daily existence for many elderly Africans. It is critical that the problems of the aged in Africa and other parts of the developing world be examined, but we must recognize that these problems do not signify a simple convergence toward a common social ill across the globe. Rather, the nature of inter-generational solidarity varies, sometimes dramatically, over time and across contexts. This study employs a comparative analysis to reveal important differences in the nature of inter-generational solidarity over time between two similar sub-regions in neighboring Ghana and Côte d'Ivoire in West Africa, and asks what explains those differences.

The existing literature does not predict this degree of spatial and temporal variation precisely because it does not adequately explain the process of social change. Theories that emphasize the socio-cultural changes wrought by the forces of modernization (Lerner 1958; Almond and Coleman 1960) or globalization (Rodrik 1997; Stiglitz 2002) fail to explain why villages with similar levels of industrialization, education, exposure to Western media, and global integration display different types of inter-generational solidarity. The wide range of arguments about the general impacts of capitalism on "traditional"

Acknowledgments: The author gratefully acknowledges the support of the Robert Wood Johnson Foundation Scholars in Health Policy Program, a Fulbright-Hays Doctoral Dissertation Research Abroad fellowship, and grants from the Social Science Research Council, Institute for the Study of World Politics, and the University of California-Berkeley's African Studies Center.

0010-4175/04/469-496 \$9.50 @ 2004 Society for Comparative Study of Society and History 
family systems, cultures, and economies (Marx 1978; Engels 1972; Weber 1964) cannot explain divergences between the two regions examined here, both of which have been integrated similarly into national and international markets through massive export production of cocoa for over seventy-five years. Furthermore, the contrasts in inter-generational solidarity in these two regions do not appear to be a result of different state social policies targeted toward the young or the old (Schlessinger and Hutchings 2002), since very few public policies explicitly target the elderly in either Ghana or Côte d'Ivoire (Morris MacLean 2002).

By comparing the processes of social change in Ghana and Côte d'Ivoire, this article reveals the mechanisms through which different histories of state agricultural policy have had indirect and unintended consequences on local social institutions. More specifically, state agricultural policies have influenced the particular ways that local people are able and choose to integrate into local and national political economies. Thus, in the 1990s, the exploitative agricultural policy of the Ghanaian state towards cocoa combined with the lower relative cost of labor and recent improvements in transportation to make tomato farming more attractive in Ghana than in Côte d'Ivoire. In what follows, I will detail how this shift in local-level production has affected the structure of social support networks. Due to the new requirements of tomato farming, Ghanaian social support networks have become more diversified, horizontally oriented, and youthful. Tomatoes are "the empire of the young," and bring dramatic new levels of wealth and power to youth. This is in contrast to Côte d'Ivoire, where both the young and the old continue to grow cocoa, and social support networks are more concentrated and vertically oriented, continuing to link youth and elders. The divergent local experiences of agrarian capitalism in Ghana and Côte d'Ivoire have changed the ways in which the boundaries of family and community are imagined in the two countries-solidarity between the young and old has been weakened in Ghana, but reinforced in Côte d'Ivoire.

My analysis is based on over eighteen months of village-level fieldwork in two culturally and economically matched sub-regions of Ghana and Côte d'Ivoire. ${ }^{1}$ In this particular area, one large ethnic group with similar pre-colonial cultural and social structures was split by the French/British boundary. After extensive discussions and preliminary site visits, two representative villages in each sub-region were selected for study. These four villages were similar in their population sizes, agricultural histories, distance from roads and markets, and the types of social services available. This research design allowed control over many potential explanatory variables such as inheritance patterns, levels of wealth, economic development, and social infrastructure. Quantitative and

1 Fieldwork was conducted from April to August 1997, and from October 1998 to October 1999 in two villages in Tano District in the Brong-Ahafo region of Ghana and in two villages in the Abengourou region of Côte d'Ivoire. Fictional names are used for these villages to protect the anonymity of the sources. qualitative methods were combined, including survey research, focus groups, in-depth interviews, collection of oral histories, ethnographic observation, and archival research.

\section{THEORETICAL CONTRIBUTIONS}

This study contributes in multiple ways to several disparate literatures that seldom speak to each other: (1) the literature on agrarian capitalism and social support networks, emerging largely from the developing world; (2) the comparative politics literature on the nature of the state and society; and (3) the welfare state and social policy literature that focuses predominantly on the advanced industrialized democracies (AICs).

First, this study extends earlier work on the development of agrarian capitalism and its effects on social support networks (Berry 1993; Watts 1983; Hyden 1980; Scott 1976). It demonstrates how particular state economic policies have stimulated different types of agrarian capitalism at local levels, transforming Hyden's "economy of affection" in divergent ways in the two cases. The findings also provide an important critique to Berry (1993:8), by demonstrating how the nature of incorporation into the colonial and post-colonial state and economy are indeed important for the contrasting ways that social relations are defined. Furthermore, while Berry $(1993 ; 1997)$ makes the important point that social relations are often contested and negotiated over time, this study shows that the fluidity of social relations occurs within the parameters of local economic and political power, which are shaped in turn by different patterns of state policymaking and local-level production strategies. Hence, not everything is negotiable and ambiguous, and some conditions are more "permanent" than others. Different patterns of social exclusion not only exist, but can persist, with important implications for social welfare and politics.

Second, the findings presented here counter much of the political science literature on the nature of the African state and society, which portrays relatively ineffectual states struggling to influence society within their borders (Herbst 2000; Reno 1998; Chazan 1988; Sandbrook 1985; Hyden 1980). While I do not argue that the Ghanaian or Ivoirian states necessarily govern with strength, efficacy, legitimacy, or democracy, I do emphasize how state policies and bureaucratic institutions matter, and how they are experienced by Africans in particular ways, even in small villages in the rural hinterlands. The research suggests that the African state is neither completely separate from society (Chazan 1988), nor wholly permeated by society through the extension of clientelist networks (Villalon 1998; Bayart 1993; Hyden 1980). Attention should be paid to how states and societies are not so much dichotomous as they are entangled and mutually constitutive (Migdal 2001; Gupta 1998). Furthermore, the study highlights the need to incorporate historicity within scholarly analyses in order to reveal the dynamics of change in African states over what Mbembe (2001) calls the longue duree. This contribution to current thinking about the 
nature of the state and social institutions is not purely theoretical, but has important policy implications. Many of the economic and social policies advocated by the World Bank (World Bank 1994) and other donors in the developing world are predicated on a simplistic conceptualization of the state and ungrounded assumptions about the existence of vibrant "informal" social safety nets, neither of which appear to function or change as commonly presumed.

Finally, the study contributes to the analysis of social policy, and in particular the problems of the aged, by incorporating evidence from the developing world. To date, much of the scholarly and media attention surrounding aging populations focuses on issues facing the United States and other AICs. The initial work conducted in developing countries has often been restricted to indepth case studies of the problems of the aged, with a goal of documenting the need for concerted policy responses (e.g., Apt 1996). ${ }^{2}$ The present study focuses on the process of change, not solely the outcomes, through a cross-national comparison which highlights the significant role played by state policies outside of the social policy arena. Furthermore, while most studies of welfare states examine macro-structural contexts to assess how social policies are determined in different AICs and over time (Pierson 1996; Esping-Anderson 1990), the analysis presented here connects the macro- to the micro-context in a novel way, investigating how different state policies affect the structure of social networks.

\section{RECENT DIVERGENCE IN LOCAL CASH CROP PRODUCTION} IN GHANA AND CÔTE D'IVOIRE

This section documents a divergence in local-level production strategies in the 1990s, with tomatoes becoming the new cash crop of the young in Ghana, but not in Côte d'Ivoire.

\section{New Tribulations for the Cocoa Farmer}

Since at least the early 1930s, cocoa has been the main crop grown in the two field site regions. Cocoa was first established in Ghana and Côte d'Ivoire in nearby regions of the same umbrella Akan ethnic group, but quickly spread to the research areas. By the 1950s and 1960s, cocoa was so dominant that both regions were considered relatively wealthy in each country. Because cocoa is a permanent tree crop that requires long-term access to a sizable area of land, ${ }^{3}$ the indigenous Akan ethnic group, primarily males, dominated cocoa production.

2 Despite its association with income support for the elderly in the United States, the literature on "social security" (Benda-Beckmann et al. 1988; Hirtz 1995; Midgley and Tracy 1996) is based predominantly on developing world case studies and defines the concept quite broadly to include all members of society, not exclusively the aged.

3 Cocoa trees require approximately five years before they can be harvested for the first time. After peaking between five and fifteen years, yields began to decline, and trees need to be replaced after thirty years.
Until the 1970s, cocoa plantations thrived, but in the early 1980s several droughts sparked bushfires that destroyed a considerable amount of the forest, including many established cocoa farms. These bushfires, combined with growing population pressures and logging for export, made it increasingly difficult to find suitable semi-forested land to reestablish the lost farms or start new ones. The reduction of forested area also generated a climactic changethe dry season is now longer and more severe, which has resulted in recurrent droughts and bushfires. Meanwhile, the surviving plantations are aging, soil fertility is diminishing, and yields are subsequently declining. Due to declining yields, migrant agricultural workers, typically from the northern regions or Sahelian countries (for example, Burkina Faso) are moving to the newer cocoa areas in the two countries, making it difficult to maintain and harvest the remaining cocoa farms.

\section{A Dramatic Switch to Tomato Farming in Ghana, but not in Côte d'Ivoire}

Surprisingly, even though farmers in Ghana and Côte d'Ivoire have faced quite similar ecological and economic challenges, they have responded differently with divergent crop production strategies. In Ghana many farmers are abandoning cocoa for tomato farming, ${ }^{4}$ while in Côte d'Ivoire farmers continue to expand their existing cocoa plantations and establish new ones. The situation in Ghana constitutes a dramatic shift in local-level production, with far-reaching implications for social relations.

\section{Cocoa versus Tomato Production Levels}

First, we need to compare the numbers of farmers and farm plots involved in cocoa and tomato production. In Ghana, only a handful of farmers (15 percent) grow cocoa on an average of 0.13 plots, while more than twice as many grow tomatoes (36 percent) on over twice as much land ( 0.32 plots). Elderly cocoa farmers confirmed that the cocoa farms in the contemporary period were "very, very small now" compared to the plantations of the past. ${ }^{5}$ The mean total cocoa production in the Ghanaian villages (US\$304) ${ }^{6}$ is significantly below tomato production in Ghana (\$465), and less than one-third of the mean value of cocoa production in Côte d'Ivoire (\$932). Self-reports and district-level production data confirm survey results that cocoa production indeed declined during the early 1990s (see Table 1). Not only are more farmers growing tomatoes in Ghana, tomatoes have become the primary income source for many more Ghanaians than Ivoirians (see Table 2).

4 Berry (1997) finds a similar commercialization of vegetable production, particularly tomatoes, in Kumawu, Ashanti region.

${ }^{5}$ Interview (anonymous) by author, Makwan, Ghana, 7 Apr. 1999.

6 The mean total production of cocoa in the Ghanaian villages was slightly higher than tomatoes, at $\$ 575$, but when one large producer (earning over $\$ 7,000$ annually from cocoa) is taken out of the sample, the mean drops to only $\$ 304$, well below tomatoes. 
TABLE 1

Decline in Cocoa Production in Tano District, Ghana

\begin{tabular}{lccccc}
\hline \hline Season & $1990 / 91$ & $1991 / 92$ & $1992 / 93$ & $1993 / 94$ & $1994 / 95$ \\
\hline Production & 3,089 & 1,710 & 1,223 & 1,195 & 1,163 \\
\hline \hline
\end{tabular}

Source: GOG (1996: 24).

The mean production of individual tomato farmers is much higher in Ghana (\$465) than in Côte d'Ivoire (\$48), and the maximum value of tomato production is nearly ten times higher in Ghana $(\$ 7,200)$ than in Côte d'Ivoire $(\$ 750)$. The existence of many large producers in Ghana reveals a qualitative change in the nature of tomato production there: In the past a few tomato plants were typically intercropped among cocoa trees for subsistence purposes; now whole plots are dedicated entirely to tomatoes. Also, in Ghana over 70 percent of survey respondents reported major changes in and out of tomato production, whereas in Côte d'Ivoire there has been almost no change. The volatility in Ghanaian tomato production is due to the short growing season (three to four months), which facilitates experimentation, and the high risks associated with marketing such a perishable crop, which cause huge variation in prices (see Table 3.).

In contrast to these striking changes in Ghana, cocoa remains the single most important crop produced in Côte d'Ivoire. Over six times as many farmers (71 percent) produce cocoa in Côte d'Ivoire as in Ghana, on more land ( 0.35 plots). Some Ivoirian farmers were less confident about the ability of their cocoa plantations to provide them with security, due to the prevalence of bushfires and drought in recent years. Nonetheless, data from surveys and in-depth interviews confirms that not only are existing plantations being expanded, but new ones are being established.

\section{A Comparison of the Demographic Profile of Tomato and Cocoa Farmers}

The demographic profile of the farmers producing tomatoes and cocoa is even more remarkable. In Ghana, tomato production is the empire of the young. One

TABLE 2

Percentage of Farmers Whose Primary Income Source is Cocoa versus Tomatoes

\begin{tabular}{llc}
\hline \hline & GHANA & CÔTE D'IVOIRE \\
\hline Primary Income from Cocoa & 11 percent & 48 percent \\
Primary Income from Tomatoes & 22 percent & 3 percent \\
\hline \hline
\end{tabular}

TABLE 3

Tomato and Cocoa Producer Prices in Ghana and Côte d'Ivoire*

\begin{tabular}{lcc}
\hline \hline Produce & GHANA & CÔTE D'IVOIRE \\
\hline Tomatoes, $\$ / 1$ box & $\$ 38-\$ 200$ & not available \\
Cocoa, $\$$ kilo & $\$ 2.19$ & $\$ 0.95$ \\
\hline \hline
\end{tabular}

*Note: Prices are purchasing power parity (PPP) adjusted.

chief, when describing the agricultural activities of his village, began with tomatoes, saying that it was "the main work for the youth."7 The queen mother of the second Ghanaian village confirmed this trend, attributing a rise in the village's standard of living to the fact that "now, the young men are up and hardworking with tomatoes." tones, also characterized tomatoes as "a young person's crop." 9 One elderly cocoa farmer in Ghana explained how he would farm tomatoes too, "if I had the strength and could." ${ }^{10}$ After a couple of years attempting to farm tomatoes, several Ghanaian farmers in their late forties and early fifties described being exhausted and unable to continue. They seemed disappointed by their own physical limitations as they spoke of the need to shift to a less labor-intensive food crop such as cassava.

Survey results indicate that most tomato producers in Ghana are between eighteen and twenty-five years of age, with only three respondents over forty. This strikingly young group is also earning much more from their production $(\$ 838)$ than any other age group. Furthermore, the top three maximum values of production between $\$ 1,400$ and $\$ 7,200$ were from farmers age eighteen to twenty-five. In Côte d'Ivoire, by contrast, tomato producers and their revenues are split relatively evenly between the ages of eighteen and fifty-five years, the same demographic pattern as is found in cocoa.

Tomato production in Ghana not only challenges prior social hierarchies based on age, but also those based on gender and ethnicity. Whereas indigenous males almost exclusively dominated cocoa production in the past, now a significant number of young women and non-Akans have started tomato farms in Ghana. ${ }^{11}$ Moreover, these new cash crop farmers sometimes matched or outpaced their Akan male counterparts in the value of their tomato production.

In comparison, Côte d'Ivoire farmers include both young and old, women,

7 Interview with Nana Amankwah, Barima, Ghana, 22 Mar. 1999.

8 Interview (anonymous) by author, Makwan, Ghana, 31 Mar. 1999.

9 Interviews (anonymous) by author, Barima and Makwan, Ghana.

${ }_{10}$ Interview (anonymous) by author, Makwan, Ghana, 7 Apr. 1999

${ }^{11}$ In Ghana, women accounted for 28 percent of all tomato producers whereas non-Akan accounted for 34 percent. 
and non-Akan. Whereas the mean age of Ghanaian cocoa farmers is sixty-two, that of Ivoirian cocoa farmers is forty. Indeed, the largest group of Ivoirian cocoa producers are twenty-six to forty years old, relatively youthful compared to Ghana where the largest group is those over seventy, including the single largest producer. In Côte d'Ivoire, the single largest producer $(\$ 12,500)$ was a forty-five-year-old Akan male and the second largest $(\$ 9,025)$ was a twentyyear-old Akan male. There is also evidence that several young men are starting new farms, and thus cocoa does not at all appear to be on the wane among members of upcoming generations, as is so clearly the case in Ghana.

While a few farmers are growing tomatoes in Côte d'Ivoire, this remains on a very small scale in comparison to farms in Ghana, and, interestingly, the farmers in Côte d'Ivoire are almost exclusively young non-Akans, and to a lesser extent women, indicating tomatoes' lack of recognized value as a true cash crop there. Only 16 percent of non-Akan tomato farmers earn more than $\$ 100$ in Côte d'Ivoire, compared to over 96 percent in Ghana, and in Côte d'Ivoire only 4 percent of female tomato farmers earn more than $\$ 100$ as compared to over 63 percent in Ghana.

\section{WHY ARE PEOPLE SWITCHING TO TOMATOES?}

\section{The History of Exploitative State Agricultural Policies in Ghana}

So why are Ghanaians switching to tomatoes as a new cash crop while Ivoirians are choosing to remain with cocoa? This question is especially perplexing in light of the appreciably higher producer prices for cocoa in Ghana compared to Côte d'Ivoire (see Table 3). Although an in-depth discussion of this question is impossible here, an abbreviated answer is important for what it tells us about changing norms of solidarity in the family and community.

First, Ghanaians are switching to new cash crops, in particular annual vegetables instead of permanent tree crops, because of a long history of exploitative agricultural policies against cocoa by the Ghanaian state. ${ }^{12}$ These policies, initiated before independence, implicitly taxed cocoa production at a much higher rate in Ghana, and this spurred cross-border smuggling when the "real" producer price was higher in Côte d'Ivoire. ${ }^{13}$ These state policies eroded the farmer confidence necessary for making long-term investments in cocoa, where yields do not usually begin until year five and do not start to peak for another decade.

12 In 1947, the Cocoa Marketing Board (CMB) was established in Ghana as a legal monopoly to export Ghanaian cocoa. The CMB fixed the local price of cocoa, normally below the world price, and in theory, saved the differential to support pice increases when the wold price was too low. In reality, when the economy deterio In reality, when the economy deteriorated, the $\mathrm{CMB}$ profits were used to cover $\mathrm{CMB}$ costs or transferred directly to central government coffers (Stryker 1990: 97). See also McMillan and Master (1999) and Frimpong-Ansah (1991).

13 In Ghana, cocoa farmers captured only 15-40 percent of the world rnarket price for cocoa whereas Ivoirian farmers received at least 66 percent of the world price (Leechor 1994, 156).
In contrast to these antagonistic policies, the Ivoirian state supported the cocoa industry, allowing private companies to market cocoa, guaranteeing the country a higher share of the world producer price, and facilitating the immigration of agricultural workers from the northern regions and Sahelian countries into Côte d'Ivoire. The Ivoirian state thus encouraged the expansion of cocoa as a fundamental pillar of its domestic power base, whereas the Ghanaian state exploited it, fearful of the cocoa regions' potential opposition threat. This explains why Ghanaian cocoa production dropped from over 560,000 tons in 1965-approximately 34 percent of the world market - to only 160,000 tons by $1983 .{ }^{14}$ Meanwhile, Côte d'Ivoire has virtually traded places with Ghana as a world leader in cocoa production, increasing production from 122,000 during the period of 1962-1967 to 580,000 tons in 1985 .

Based on this history of extractive agricultural policies towards cocoa in Ghana, one would predict that Ghanaian farmers would resist adopting other permanent crops. Thus, this legacy of state exploitation explains why, despite "the hard sell" and multiple incentives offered by agricultural extension agents, Ghanaians have refused to adopt another permanent crop such as coffee. ${ }^{15}$ Not one Ghanaian farmer reported growing coffee, whereas 43 percent of Ivoirian farmers polled in the survey cultivated coffee, with a mean annual value of production of $\$ 291$

\section{The Lower Price of Labor in Ghana Relative to Côte d'Ivoire}

While the antagonistic policies of the state do elucidate why Ghanaians may have turned away from cocoa and other tree crops, it does not explain why they turned toward tomatoes. Another key part of the story is that the relative price of labor is much cheaper in Ghana than in Côte d'Ivoire. Unlike cocoa, tomatoes do not require large plots of land, but they do call for large inputs of labor. Tomato plants must be watered individually every day, a backbreaking task that usually begins at 5 a.m. ${ }^{16} \mathrm{Also}$, because tomatoes are not permanent plants, they must be replanted after each harvest, three times a year, or every three to four months. Cocoa trees, on the other hand, can live for between thirty and fifty years. Cocoa also requires minimal labor throughout the year to maintain the trees, with only two, predictable peaks of labor during the major and minor harvests.

Until recently, the Ivoirian government made it quite easy for foreigners from

14 After adopting liberalization, Ghanaian cocoa production increased to 247,000 tons by 1990 but then leveled off (Gyimah-Boadi 1995; Leechor 1994:156) and never regained its former peak.

15 Agricultural extension agents in Ghana reported serious resistance to coffee cultivation despite offers of free fire-resistant seedlings, technical assistance, and favorable producer prices. In contrast, agricultural extension agents in Côte d'Ivoire noted an increase in coffee production in recent years.

16 Watering must be done early in the field site villages, for two reasons: One, the water source closest to the field will be exhausted if you are the last one to arrive. Second, the plants must be soaked with water before the sun begins to scorch them. 
Mali or Burkina Faso to migrate to and work in the cocoa regions. Hence, historically, Ivoirians have depended on migrant labor to work their plantations much more exclusively than have farmers in Ghana, where the government did little to facilitate the influx of migrant labor. Now, however, since fires and other ecological changes have reduced cocoa yields over time, it has become increasingly difficult to attract and pay for foreign labor to work on Ivoirian farms in the field site region. On the supply side, Burkinabe and other workers prefer the newer pioneering cocoa regions in the West, where the same percentage of a larger yield earns more money. On the demand side, Ivoirian cocoa farmers can no longer afford to hire labor.

The Ivoirian government aggravated this situation further by shifting tactics in the 1990s and making it much more difficult for foreign workers to immigrate and remain legally in the country. The price of identity cards skyrocketed, and now anyone who looks "foreign" is routinely harassed for their papers. ${ }^{17}$ The government is also pursuing a land registration policy that will reappropriate land that had been sold or given to foreigners in the past and give title to the "original" indigenous owners. For the above reasons, foreign labor is in short supply and Ivoirians have a strong incentive to stick with the less labor-intensive cocoa production.

The same dilemma with regard to the scarcity of migrant labor troubles Ghanaians, but they appear to have more options. First, Ghanaians never relied as heavily on migrant labor, and farmers and their families have always worked their own farms, even in the good times. While approximately half of all respondents in both countries replied affirmatively that they had purchased some type of agricultural labor during the previous year, the mean expenditure was much higher in Côte d'Ivoire (\$67) than in Ghana (\$6). This most likely reflects the higher proportion of permanent workers hired in Côte d'Ivoire, as well as the higher costs of labor for permanent and daily workers there (see Table 4). Second, the Ghanaian economy has experienced more downturns than the Ivoirian one, and so Ghanaians have been forced to adapt and be more flexible and willing to work in any sector. For example, many more Ghanaians reported working "by day" if necessary to earn additional income whereas this practice was rarely, if ever, acknowledged in Côte d'Ivoire. Third, the survey research documented that Ghanaian respondents' children lived closer to their parents' homes than do the Ivoirians' children. Thus, due to the greater availability of cheaper family labor, Ghanaians are better able to switch to tomato farming, with the high daily labor inputs it demands.

\footnotetext{
17 This situation has deteriorated gravely since the time of fieldwork due to recent ethnic civil
} war which has spurred anti-immigrant violence and the subsequent flight of many non-Akans.
TABLE 4

Price of Agricultural Labor in Field Sites

\begin{tabular}{lcc}
\hline \hline & GHANA & CÔTE' D'IVOIRE \\
\hline Daily Wage Rate & $\$ 0.71-\$ 1.66 /$ day & $\$ 1.20-3.33 /$ day \\
Annual Contract Amounts & $*$ & $\$ 100 \$ 167 /$ year \\
\hline
\end{tabular}

*Missing data.

Recent Improvements in Transportation Facilitate Tomato Marketing in Contemporary Ghana

While the lower cost of labor explains why Ghanaians were more likely to adopt tomatoes than were Ivoirians, recent improvements in transportation in Ghana explain why Ghanaians have adopted tomatoes within the past decade, rather than earlier. Transportation improvements associated with the adoption of structural adjustment have facilitated the transport of more perishable crops like tomatoes to domestic markets. Throughout the 1970s and early 1980s, transportation in Ghana was extremely difficult. Roads were in serious disrepair, as were the few vehicles plying the routes. Cocoa farmers in general were minimally affected by these difficulties since cocoa can be stored for long periods of time and was usually sold at nearby purchasing centers. Beginning in the 1980s under Ghana's structural adjustment program, the government began improving the road infrastructure throughout the country. With an infusion of foreign exchange from World Bank loans, the government was also able to increase gasoline imports. ${ }^{18}$ Imported car parts also became more readily available, resulting in a marked increase in the number of vehicles circulating between markets. These transportation improvements, combined with the availability of lower-cost labor and the history of exploitative policies against cocoa, have encouraged farmers to drop cocoa in favor of tomato production in this region of Ghana.

\section{THE IMPLICATIONS OF DRAMATIC CASH CROP CHANGES} FOR SOCIAL SUPPORT NETWORKS

\section{Redefining Family and Community Solidarity}

The dramatic switch away from cocoa to tomato production in Ghana has stimulated a redefinition of family and community solidarity at the local level. First,

${ }^{18}$ Due to the lack of foreign exchange for imports, gasoline was chronically in short supply: The Ghanaian government monopoly on distribution facilitated monopoly rents and costly fuel prices. 
because so few Ghanaian farmers maintained, replanted, or expanded their cocoa plantations in the field site region after the bushfires that began in 1983, cocoa farms no longer promise as viable a future. The high levels of poverty in this region were unknown during the heyday of the cocoa boom. As one man noted, "Some people live the whole day and can only afford to buy kenkey. We have a big problem here. All of our farms have been destroyed. At the time that we had our cocoa farms, such things were non-existent." 19 Cocoa is no longer viewed as the way to become prosperous; now tomatoes are.

But, this new type of cash crop production has dramatically different implications for social relations than did cocoa. As seen above, a new group of younger tomato farmers has been able to accumulate wealth relatively rapidly. This substantial and rapid increase in the economic power of youth is already presenting a challenge to traditional social, economic, and political hierarchies where older Akan men with long-term investments in large cocoa plantations historically were the wealthy elders of the village.

It is not only the new dynamics of wealth accumulation that are overturning previous power structures. Within this new production system, tomato farmers face different sets of input requirements than did cocoa farmers. Tomato farmers need labor more than they need land, the inverse of cocoa cultivation needs. Chart 1 shows how these new needs are altering the incentives to maintain social ties with various social groups, thereby stimulating changes in the structure of social support networks. ${ }^{20}$

These new needs for little land but substantial amounts of labor create incentives to maintain highly diversified social support networks in Ghana, in contrast to the more concentrated networks found in Côte d'Ivoire. Furthermore, the relative costs and benefits of giving and receiving social support to an older parent or uncle versus a younger friend have changed in Ghana, but not in Côte d'Ivoire.

The variation in the patterns of social relations between cocoa and tomato farmers in Ghana and Côte d'Ivoire is demonstrated by the survey data shown in Table 5. First, in both Ghana and Côte d'Ivoire tomato farmers give help to people with whom they share a more diverse set of social ties, while cocoa farmers concentrate their help on nuclear family members, particularly in Côte d'Ivoire. $^{21}$ The data also shows that giving to friends is not as important for co-

19 Men's focus group (anonymous), Makwan, Ghana, Apr. 1999.

20 This economistic way of conceptualizing social support networks is based on local-level, indigenous perspectives. While notions of exchange and reciprocity were important components of social support in both Ghana and Côte d'Ivoire, this does not mean that other less concrete and less tangible costs and benefits do not enter into an individual's analysis, or that this analysis necessarily takes place consciously.

${ }^{21}$ In order to document actual local-level patterns of social exchange, a survey instrument was designed that asked respondents what help they had received and given over the past twelve months. While the recall would have been arguably better if the time period had been compressed to only the previous week or month, the data would have been extremely uneven across village field sites
Chart 1. Linking Production to Social Support Networks

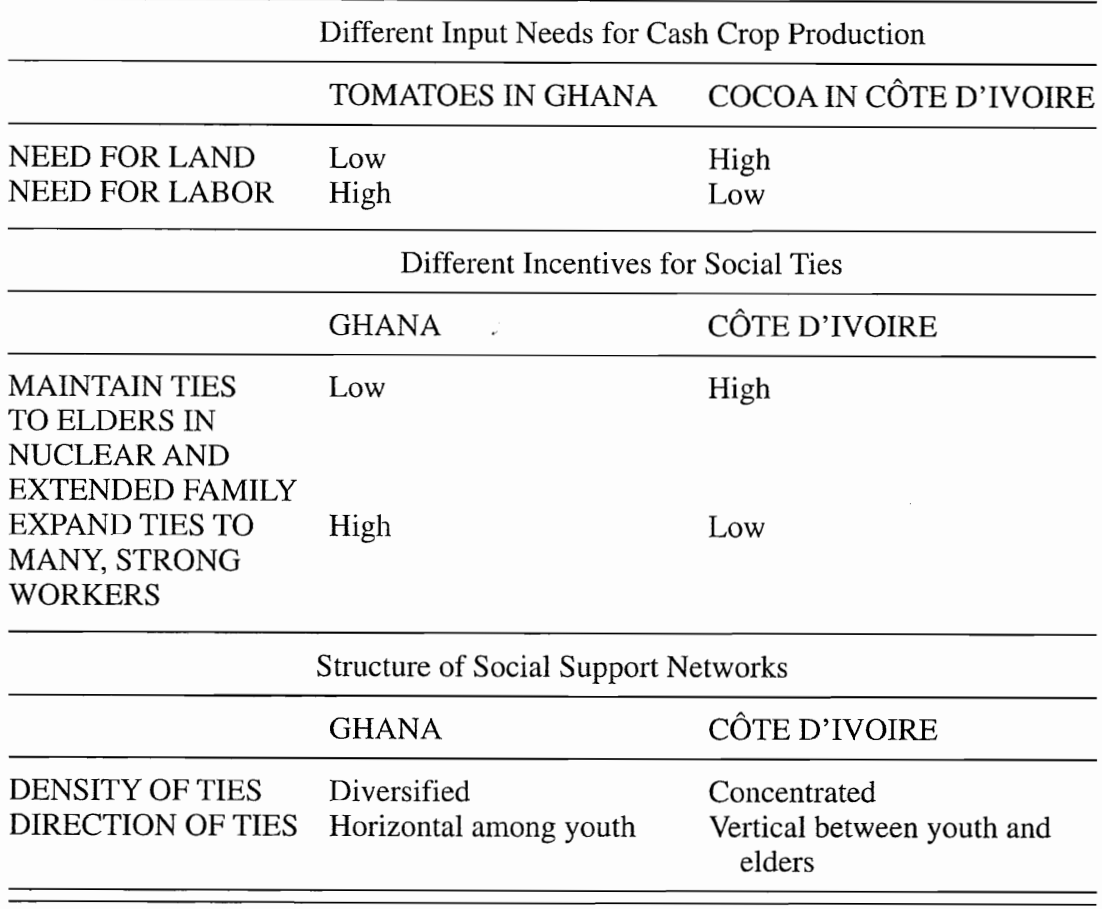

coa farmers as for tomato farmers, in either Ghana or Côte d'Ivoire. The study found that tomato farmers in Ghana continued to give the most significant amount of social support to their extended family, but what is obscured is the ages and/or specific social relations of those to whom that support is offered. For example, the qualitative data suggests that the young tomato farmers in

due to seasonality bias. To improve respondent recall, respondents were reminded of various seasonal events beginning twelve months prior to the interview. Also, after an initial open-ended questo pay for hospital or clinic fees; help to pay for medicine; help to receive care from a traditional healer or herbalist; help with the costs of a funeral; help to get engaged or married; help to pay school fees; help to provide school books or supplies; help to provide accommodation; help with food or prepared meals; help with cloth, clothing, or shoes; help with tools; help by working for someone without pay; help with land; help in paying a debt; help in starting a business; and, lastly, help with anything else not already mentioned. While social networks are, of course, not reducible to monetary exchanges, transfers of cash or in-kind value are believed to be leading indicators of the depth and extent of these network. Respondents were asked for the paticular social tie to which or from extent of these networks which they gave or received help. I then aggregated these particular ties into broader categories such as nuclear or extended family. 
TABLE 5

Social Support Given to Various Social Ties from Cocoa Versus Tomato Farmers

\begin{tabular}{|c|c|c|}
\hline $\begin{array}{l}\text { PRIMARY SOURCE } \\
\text { OF AGRICULTURAL } \\
\text { INCOME }\end{array}$ & $\begin{array}{l}\text { GHANA } \\
\text { MEAN VALUE OF HELP } \\
\text { GIVEN IN U.S.\$ }\end{array}$ & $\begin{array}{l}\text { COTTE D'IVOIRE } \\
\text { MEAN VALUE OF HELP } \\
\text { GIVEN IN U.S.\$ }\end{array}$ \\
\hline COCOA & $\begin{array}{l}\mathrm{n}=21 \\
\text { help to nuclear }=4.39 \\
\text { help to extended }=7.43 \\
\text { help to friends }=1.41\end{array}$ & $\begin{array}{l}\mathrm{n}=95 \\
\text { help to nuclear }=117.67 \\
\text { help to extended }=40.22 \\
\text { help to friends }=3.90\end{array}$ \\
\hline TOMATOES & $\begin{array}{l}\mathrm{n}=41 \\
\text { help to nuclear }=1.68 \\
\text { help to extended }=16.21 \\
\text { help to friends }=3.84\end{array}$ & $\begin{array}{l}\mathrm{n}=5 \\
\text { help to nuclear }=3.61 \\
\text { help to extended }=5.32 \\
\text { help to friends }=4.51\end{array}$ \\
\hline
\end{tabular}

Ghana most likely give more support to their younger siblings and cousins than to their elderly uncles.

\section{A Diminished Need for Land in Ghana and Its Implications for Social Networks}

Because these younger Ghanaian tomato farmers do not need land as much as labor, inheriting the cocoa plantation of one's father and/or uncle had become less material than maintaining a wide network of family, friends, and others. Since only a small plot of land is required for tomatoes, ${ }^{22}$ and for only a short period of time, there was no need to invest heavily in one or two particular relationships, a parent or uncle for example. A farmer could borrow or rent the land from anyone rather than inheriting or obtaining the consent of elders for the long-term customary use of family land. Thus, because family land has become relatively less important economically, the incentives for maintaining particular social ties have also become less compelling.

Then, in a positive feedback loop, the fact that fewer young farmers are using family land in Ghana further weakens traditional social support networks. When a person does use family land to establish a cocoa plantation, their incorporation into social support networks becomes tighter and more obligatory. Family land is usually not given or sold but rather entrusted to family members "to take care of" for relatively long periods of time. Because cocoa production usually occurs on family land, the revenues are perceived as less "autonomous" and more closely tied to family welfare. Thus, a wealthy relative who refuses to help a needy family member can be questioned and held accountable if his

22 Data collected at the district level in Ghana confirms that the average cocoa farm is now 3.6 acres, whereas the average farm size for vegetable crops is only 0.5 acres. wealth was gained through family property, as is often the case with cocoa. "He can even be sacked for another person to be put in charge of the cocoa farm."23 On the other hand, if his wealth was acquired through his own means, particularly on non-family land, as is usually the case with tomatoes, "nothing can be done to him."24

In addition to land, tomato farming does require a certain amount of inputs for pesticides, spraying machines, and other tools. Again, this financial assistance need not be provided by a family member but could be given by anyone as a loan or as an investment in exchange for a share of the crop returns. In fact, it appears that this sort of assistance is frequently given in conjunction with the needed land as part of sharecropping arrangements.

The survey research confirms these predicted differences in land tenure patterns in tomato versus cocoa production in Ghana and Côte d'Ivoire. While cocoa farmers in Ghana exclusively used either their own property (63 percent) or family land (37 percent), the majority of tomato farmers either made sharecropping arrangements (38 percent) or rented land (15 percent). While a substantial proportion of tomato farmers did use family land (38 percent), only a small minority used their own property ( 9 percent). In comparison, in Côte d'Ivoire the overwhelming majority of farmers grew tomatoes on family land (48 percent) or on their own property (38 percent), and only 15 percent rented or made sharecropping arrangements. These tenure patterns also confirm the earlier finding that tomatoes are being cultivated as a cash crop in Ghana, but not in Côte d'Ivoire.

A comparative analysis of land tenure patterns disaggregated by age group shows how the use of family land has declined in importance for younger farmers in Ghana, who are now primarily involved in tomato production. Younger farmers in Côte d'Ivoire, on the other hand, remained actively engaged in cocoa production. In Ghana, at least as many, if not more younger tomato farmers rented land or sharecropped instead of using family land, while middle-aged tomato farmers more exclusively sharecropped, and older farmers did not grow tomatoes at all. In Ghana, older cocoa farmers tended to own their plots whereas the use of family land was most important to the few, younger cocoa farmers. This general trend holds true in Côte d'Ivoire as well, although sharecropping was more important for younger cocoa farmers. This distinction reflects the greater role of migrant labor in cocoa production in Côte d'Ivoire. ${ }^{25}$ The changing relative importance of land as an input in tomato production is one

\section{Women's focus group (anonymous), tape recording. Barima, Ghana, Mar. 1999. \\ ${ }^{24}$ Men's focus group (anonymous), tape recording. Barima, Ghana, Mar. 1999.}

${ }_{25}$ Migrants represent 52 percent of those farmers who gain their primary income from cocoa production in Côte d'Ivoire. The dominant land tenure pattern for those non-Akan cocoa farmers is sharecropping (56 percent sharecrop; 31 percent own the land; 10 percent use family land; and 3 percent use land at no charge). The idea that migrant workers might constitute a significant proportion of the young sharecroppers is supported by the survey data. Younger non-Akan cocoa farmers tend to sharecrop, while older ones tend to own their land. 
reason that informal social networks in Ghana are relatively shallow but more diversified than in Côte d'Ivoire. It also begins to reveal why networks are more horizontally oriented (linking similar age cohorts) in Ghana and more vertically oriented (connecting youth to elders) in Côte d'Ivoire. If the need for land under the new system of tomato production is diminished and can be satisfied through a multiplicity of social ties, the former power of nuclear and extended family member elders over youth is eroded.

\section{The Role of Inheritance Laws}

While inheritance laws have also changed over time, I argue that the reorientation of social networks is primarily due to the shift in local-level production strategies, not to changes in official legal frameworks affecting inheritance. In both Ghana and Côte d'Ivoire, legislation has been passed to encourage a more patrilineal inheritance system. ${ }^{26}$ In Côte d'Ivoire, legislation that designates the spouse and children as the sole inheritors was enacted much earlier, in 1964. Later, in 1985, the Ghanaian government introduced the Intestate Succession Law, which promotes the security of widows and children but also specifies that one third of the estate be given to the extended family.

One might predict that both laws would encourage more nucleated social networks, particularly in Côte d'Ivoire where allocation to the extended family is not specified. While both laws do appear to provide some support for the rights of the nuclear family, neither is consistently enforced at the local level. When asked if children inherit from their father, one Ivoirian woman replied skeptically, "Here, one talks about it like that, but really... those who inherit are one here, one there." 27 Families are seeking the application of the law and shaping their own "customs" on a case-by-case basis. Since there is no commonly held expectation of a consistent enforcement of the statutory law to benefit the nuclear family, there is little evidence that these official legislative changes are the primary causal factors shaping variations in social support networks.

Two puzzles remain which are not adequately explained by the changes in legal frameworks but are better explained by changes in production. First, why would the extended-family system appear to be relatively vibrant in Côte d'Ivoire even forty years after the passage of a nuclear family-oriented law? The data reveals that that the continued viability of cocoa production at the local level in Côte d'Ivoire strengthens the incentives of young Ivoirian farmers to maintain ties with their extended families, whereas in Ghana the system of tomato production erodes these incentives. Second, if legislation potentially strengthens the role of the nuclear family in both cases, why do friends appear

26 Both laws potentially conflict with the matrilineal system of the indigenous Akan, the dominant ethnic group in both field site regions. Historically, in Akan areas, when a man died the man's relatives on his mother's side claimed rights to his property, often leaving his wife and children homeless and destitute.

27 Women's focus group (anonymous), Opanin, Côte d'Ivoire, Sept. 1999. to be so important in Ghana but not in Côte d'Ivoire? The answer is that the need for less land and more labor to grow tomatoes in Ghana fosters a more diversified social support network such that the role of friends is expanded.

\section{A Greater Need for Labor and the Implications for Social Networks}

The shift to tomato farming in Ghana has not only reduced the demand for larger plots of land, but has also increased the need for labor. The demand for labor is not generic, however. Because the work on tomato farms is back-breaking, those who can be of genuine help are younger, more active, and physically fit. One Ghanaian man, in discussing the rise of tomato farming in his village, asserted that, "Strong people do it . . . very strong. It's difficult work." 28 Thus, it is the younger and stronger men and women who help each other with watering and weeding. Younger men and women may lend a hand during the harvest, or money to help another young person plant. Respondents of all ages confirm that the young tomato farmers in Ghana are now becoming an increasingly common source of loans for local people. ${ }^{29}$ This overturns traditional hierarchies where elderly cocoa farmers historically provided loans. One eighty-fiveyear-old cocoa farmer said despondently that, "In the past, I could help anyone, even to the extent of borrowing on their behalf. . . Now, nobody would even come. . . I can't help anyone now."30 Increasingly, young tomato farmers also appear to be the recipients of loans given by local people, since they are perceived as capable of repaying the loans after their tomatoes are sold. ${ }^{31}$

We can hypothesize that in Ghana social networks are based increasingly on horizontal ties among family members and friends of the same age cohort. Unfortunately, because the survey questionnaire did not ask directly the age of the donors and recipients of social support described by respondents, it is impossible to test definitively with this data set whether social support networks are denser among members of the same age cohort. Other quantitative indicators, however, suggest that networks are more horizontal in Ghana than in Côte d'Ivoire. Table 6 demonstrates how siblings are a particularly important social category for help in Ghana, whereas giving to parents, grandparents, aunts, and uncles is not as substantial there as in Côte d'Ivoire. Ghanaian respondents also tend to allocate a greater percentage of their total help to friends and others than do Ivoirian respondents. Particularly when one takes account of the cultural emphasis placed on age hierarchies, it is more likely that a respondent's friends would belong to approximately the same age group than not.

28 Interview (anonymous) by author, Barima, Ghana, 21 Feb., 1999.

${ }^{29}$ Survey interview (anonymous) by author, Barima, Ghana. Interview (anonymous) by author, Makwan, Ghana, 9 Apr., 1999.

${ }^{30}$ Survey interview (anonymous) by author, Makwan, Ghana

31 Women's focus group (anonymous), Barima, Ghana, Mar. 1999. 
TABLE 6

Social Support Given to Various Social Ties by All Respondents

\begin{tabular}{|c|c|c|c|c|c|}
\hline \multirow[t]{3}{*}{ GHANA } & \multicolumn{5}{|c|}{ CÔTE D'IVOIRE } \\
\hline & & $\begin{array}{l}\text { PERCENT OF } \\
\text { TOTAL HELP }\end{array}$ & & & $\begin{array}{l}\text { PERCENT OF } \\
\text { TOTAL HELP }\end{array}$ \\
\hline & $M E A N$ & TO & & $M E A N$ & TO \\
\hline SOCIAL & TOTAL & PARTICULAR & SOCIAL & TOTAL & PARTICULAR \\
\hline CATEGORY & $\operatorname{VALUE}(\$)$ & GROUP & CATEGORY & $V A L U E(\$)$ & GROUP \\
\hline All social ties & 28.91 & - & All social ties & 117.5 & - \\
\hline Nuclear family & 13.37 & 46 percent & Nuclear family & 81.51 & 69 percent \\
\hline Extended family & 10.24 & 35 percent & Extended family & 28.09 & 24 percent \\
\hline Parents & 0.80 & 3 percent & Parents & 5.24 & 5 percent \\
\hline Siblings & 4.86 & 17 percent & Siblings & 13.04 & 11 percent \\
\hline Friends & 3.74 & 13 percent & Friends & 4.30 & 4 percent \\
\hline Others & 1.56 & 5 percent & All social ties & 117.5 & - \\
\hline
\end{tabular}

INTER-GENERATIONAL SOLIDARITY IN CRISIS

Given the difficulties in proving indisputably that social networks are denser among those of the same age cohort, due to the limitations of the data, I would like to compare the predicted effects of different patterns of social networks on inter-generational solidarity. If social networks do diverge in the ways I have suggested, one would predict that solidarity between the young and the old would be under more serious strain in Ghana than in Côte d'Ivoire. The following four points provide qualitative evidence to support this prediction, that treatment of the elderly has indeed worsened more gravely and rapidly in Ghana than in Côte d'Ivoire.

\section{The Characterization of Inter-Generational Solidarity by Youth}

First, let us compare how the youth and elderly in Ghana and Côte d'Ivoire themselves characterize the nature of inter-generational solidarity. While both the older and younger individuals were interviewed, the comments from the youth were particularly insightful. The elderly in both countries tended to complain about a lack of respect and the inadequacy of the care they received, whereas the opinions expressed by youth in Ghana and youth in Côte d'Ivoire were quite different regarding how the elderly were treated and why. I assert that the discontented comments from the elderly in both countries reflect their long-term expectations having been frustrated by the current economic crisis. They likely took care of their own parents during the boom times, and thus their expectations of their own futures developed accordingly.

In Ghana, a young Akan man explained perceptively how the new system of tomato farming had inverted traditional hierarchies, resulting in a lack of respect for the elderly among self-sufficient youth.

The town is even sinking ... The youth do not respect the elders ... [Morris MacLean queries: "Why don't they respect them?"] The youth say, "I'm caring for my own so they can't tell me what to do." It's because the aged can't afford for the young. The only job we do is tomatoes. The aged are sitting in the house and can't go to farm. So the young have money, and the old do not. They can't respect the old man because he doesn't have any money ... This is a sickness to all Ghanaians ... There has been a problem with respecting the elders for a long time, even since 1900, say, but now it's growing bigger and bigger. Now, maybe it's 80 percent who don't respect the elders ... But, the older ones have done something for the younger ones. They bathed us and did everything for us. We should be giving them things. It's not a good thing that the young don't respect them. This is how God said we should do [respect our elders]. ${ }^{32}$

In the comments of this young man and others, it seemed clear that this was not a totally new problem, yet, the problem has been significantly aggravated by recent economic changes, in particular those in the local system of cash crop production. The above comments also reveal that the changes in Ghana are not trouble-free for anyone: while the elderly are despairing or resentful, the youth often express guilt.

In contrast, in Côte d'Ivoire, because cocoa production still promises the possibility of a prosperous future, young people have an incentive to maintain their relationships with their elders, and in particular to stay well-connected to their parents and uncles from whom they could inherit sizeable cocoa plantations. As one young Akan man boasted, “ . . . when I inherited from my uncle, ask anyone here, what didn't I have as far as plantations go?"33 A young Akan woman summarized this idea of continuing reciprocity between youth and elders: "If the elderly person has well-off children, then these children will take good care of him and send him money at the end of every month. This happens only if you worked hard in your youth." 34 This long-term reciprocity seems to be considered "normal" to both the young and the elderly in Côte d'Ivoire. One elderly Akan woman used a proverb to explain the ongoing cycle of help: "I raised my children from when their teeth first came in. They also, can help me until my teeth fall out." 35

Because of the continuing relevance of the matrilineal system, discussed above in regards to inheritance, parents are not the only significant figures to the young-maternal uncles are important too. Their continued importance in Côte d'Ivoire is exemplified by the comments of one nephew who lamented the hard times brought on by the death of his own uncle: "My uncle was everything for me; he was the one taking care of me." Many more respondents in Côte

\footnotetext{
${ }^{32}$ Interview with church and leader (anonymous), Barima, Ghana, 24 Feb. 1999.

33 Men's focus group (anonymous), Opanin, Côte d'Ivoire, Sept. 1999.

34 Survey interview with a twenty-three-year-old married Akan woman who had one child, (anonymous) by author, Opanin, Côte d'Ivoire.
}

35 Interview with elderly woman (anonymous) by author, Kyere, Côte d'Ivoire, 20 Aug. 1999. 
d'Ivoire than in Ghana mention uncles as important sources and outlets for help, often citing them before or even without reference to fathers. Many respondents described fulfilling their duties as an uncle in terms of supporting or fostering their nephews and nieces. For example: "It's me that always takes care of the children of my sisters. When I inherited, I took care of the children like I should do. I did it without a second thought." ${ }^{36}$ Ironically, despite long-established legislation in Côte d'Ivoire that is unambiguously supportive of a father's children, uncles and nephews appear to remain more important there than in Ghana. This enduring relevance of uncles not only concentrates network ties within extended families, as discussed earlier, but it also strengthens inter-generational ties between youth and elders.

\section{Caretaking of the Elderly in Practice: A Comparison}

Having examined how Ghanaians and Ivoirians generally characterize relations between youth and elders, now we will compare how the two groups actually behave vis-à-vis the elderly in their own family. First, fewer people in Ghana (27 percent) described taking care of an elderly person in comparison to Côte d'Ivoire (52 percent). One elderly mother of seven children in Ghana described how life was "always" hard because: "No one is taking care of me. I have to take care of myself so I'm always in hardship." 37 Many respondents in Ghana appeared to be working under the assumption that the elderly would be self-reliant, but noted that this self-reliance had been undermined with the marginalization of the elders' cocoa farms. One thirty-three-year-old Akan man in Ghana explained, "Formerly, the elderly didn't need anyone to care for them since they had their own cocoa farms. But with the destruction of all of these cocoa farms, they, just like the young ones, had to do their own petty farming to care for themselves." 38 Thus the decline of cocoa production in this region of Ghana had in a sense leveled the playing field between young and old, but the old were less prepared to play the new game in town: tomato farming.

In comparison, respondents in Côte d'Ivoire did not emphasize the self-reliance of the elderly as Ghanaians frequently did. Children still articulated a responsibility to take care of their mothers and fathers, in collaboration with their siblings. Respondents frequently opined that children should care for their "own" parents and that the village would not take up this responsibility. "The old man who put you in the world, you can't drop him and it's not the neighbors either who are going to leave their elderly to take care of yours while you are there. It is you or your brothers who can take care of the old man in your house." 40

\footnotetext{
36 Men's focus group (anonymous), tape recording, Opanin, Côte d'Ivoire, Sept. 1999.

37 Survey interview (anonymous) by author, Barima, Ghana.

38 Survey

39 Men's and women's focus groups (anonymous), tape recordings, Kyere, Côte d'Ivoire, Aug. 1999

40 Men's focus group (anonymous), Kyere, Côte d'Ivoire, Aug. 1999.
}

A continued concern for the elderly is confirmed by focus-group discussions where participants described how one "must help" an elderly person. "If he needs help, it is necessary to give him care, give him something to eat. If he can't get up, one can even bathe him and wash him." ${ }^{41}$ Although there were exceptions, in general Ivoirians responded by describing how one cares for the elderly in their family, not whether one should.

\section{Changes in Meal Preparation for the Elderly}

There are substantial differences between the preparation of meals for the elderly in Ghana and Côte d'Ivoire, a dissimilarity directly connected to the new system of tomato production found in Ghana but not in Côte d'Ivoire. In Ghana, most of the elderly and children buy at least one of their meals from the many prepared food sellers that line the main street and spread throughout the village. Since everyone is needed on the tomato farms very early to water, no one stays behind to cook for the family compound as was done in the past. One elderly man described how household eating patterns in Ghana had changed and the negative impact this had on the elderly:

In the past, the children of the elderly were there, and the nephews were around so they didn't allow the elderly to work. They gave them food and everything. For example, my father was in Ohia and since they didn't buy their food, if the old man wanted to eat ten times a day, it was no problem. Foodstuffs were in abundance, bush meat was all around, and there was livestock too; one only had to buy salt. Whatever the old man wanted, they could provide easily. Even oil, like palm oil, they made at home, so they always had plenty. It's not this way today. The elderly are not looked after as they were before. Now, they go and take the bowl and buy food. The old man even has to send for food. If you are elderly and you were irresponsible and didn't take care of your children, then you will definitely go hungry. But if you were responsible, then, they will buy food for you ... Now the women are also working so they buy something and then go straight to work . . . We buy a lot more of our food now than we used to. We've always had farms, but now they're doing it for the money. They're cultivating tomatoes now and you have to work very hard to earn a lot of money, to get good yields. ${ }^{42}$

Another Ghanaian man with a tomato farm said that he and his wife needed to go out early to water the tomatoes, and so their children were sent with 100 or 200 cedis each to buy kenkey or something else to eat. He rationalized that if his wife were to stay and cook for the whole family, she would be delayed until 10 a.m. or so. "In the olden days, we may have sent the kids to the extended family, but now, we can't. They may have their own problems and burdens and not see them as deserving. They may see it as 'stealing' even!"43

In Côte d'Ivoire, by comparison, fewer elderly and children purchased their morning meals. This was evidenced by the smaller number of prepared food sellers there. While a plethora of food sellers lined the main thoroughfare and

41 Women's focus group (anonymous), Kyere, Côte d'Ivoire, Aug. 1999.

42 Interview with seventy-four-year-old man (anonymous) by author, Barima, Ghana, 4 Mar1999.

Interview with man in his late fifties (anonymous) by author, Barima, Ghana, 21 Feb. 1999 
dotted the courtyards all around the Ghanaian villages, in each of the Ivoirian villages there were perhaps three "beignet" and other sellers at the village market, and one or at most two "chop" houses. And the differences were not only quantitative - the Ghanaian sellers also tended to prepare more substantial "meals" (i.e., staple dishes such as kenkey, foufou, and banku with accompanying soups) rather than "snacks" (i.e., fried dough, plantain, or yam). Those few who did buy food in Côte d'Ivoire appeared to do so because their parents or caretakers had to leave early to walk to distant cocoa farms, not to water tomato plants.

\section{Changes in Accommodation of the Elderly}

Changes in the architectural design of homes suggest a more marked decline in the accommodation and daily supervision of the elderly in Ghana than in Côte d'Ivoire. In Ghana, a greater number of smaller, rectangular homes without the more 'traditional' courtyard are being constructed on the outskirts of the village center, primarily by younger Akan men with extended families in town. Interestingly, the changes in architecture toward smaller, nuclear family houses are both an indicator of current changes in family relations and a catalyst for further change along the same lines. First, smaller houses do not facilitate cooking together, which hinders the pooling of resources and the monitoring of food intake by elderly family members. One elderly man describes how the architectural changes intertwine with the preparation of food and care for young and old family members: "Formerly, there were more people than what you see today in one compound. There might be an old man like myself, children, grandchildren, and nephews. I knew this, so I built this big family house back in 1950 . In the olden days, we used to have BIG pots in which we cooked all the food for everyone. We may have had two mortars for foufou and all cooked together. Nowadays, each person is building his own house for his smaller family. Now, we're separating into separate, smaller houses and so food is not done together. Everyone is separating." ${ }^{4}$ Second, the more restricted allotment of space in the smaller houses does not as easily allow for extended overnight visits, as is usually the custom during ceremonies such as funerals. Lastly, the separate and usually less-central locations of the smaller homes impede the supervision and attentive care of elderly family members.

The social implications of these changes in architecture are not lost on Ghanaians. The construction of such a house by an individual seems to be viewed both positively and negatively, as an assertion of economic power and independence. Several people pointed proudly to half-completed walls, noting that when able to buy more materials they would continue building their small house for the security of their wife and children. Other, older family members

\footnotetext{
${ }^{44}$ Interview with seventy-four-year-old man (anonymous) by author, Barima, Ghana, 4 Mar
} 1999. would note desolately that one of their younger relatives had abandoned the family compound to build their own smaller house.

In Côte d'Ivoire, by contrast, there appear to be fewer smaller houses, particularly among the indigenous Akan. ${ }^{45}$ The styles of large family houses in this region of Côte d'Ivoire were more varied, however, being of three basic types: (1) the older style of large rectangular house with many rooms opening onto an open-air central courtyard (the type found more exclusively in Ghana); (2) a newer style of "villa" with several rooms opening onto an enclosed living room area; and (3) the most recent "motel-style" house with two or three long blocks of rooms, usually arranged in an " $\mathrm{L}$ " or horseshoe shape, looking out onto a larger open area.

Based on respondent accounts of local history, it appears that the few "traditional" courtyards remaining were constructed many decades ago. During the cocoa boom times most were replaced with villas, which are now frequently in a state of disrepair due to the recent hard times. Houses built within the past decade follow the third style. Since all of the rooms are not under the same square roof, this "motel-style" seems to be a relatively simple and less expensive model of construction. This style more readily facilitates piecemeal building as individuals are able to finance the necessary materials, and need to accommodate growing families. ${ }^{46}$ All three types of houses can and do accommodate relatively large or multiple households, and all three are referred to as family compounds.

While all of the family house styles in Côte d'Ivoire shared one central, outdoor kitchen area, cooking was not necessarily as communal as in the past. Sometimes multiple households would pool resources and cook "in one big pot," and at other times each household cooked with their own ingredients in their own pots. Still, the centralization of cooking facilitated a greater sharing of resources and information about each other's food security than when people lived in completely separate, nucleated houses, as was more often the case in Ghana. We can see this evolution of architectural styles as representing adaptations to changing needs, and as allowing the family compound to persist in the face of mounting pressures.

Before concluding this section, a few caveats must be presented in each case. First, in Ghana, while the shift in local-level cash crop production and social relations has been dramatic, it remains in process. Solidarities are being strained and renegotiated but they are not completely reconstructed. Not all young tomato farmers are able to forfeit all social ties to their elders, particularly in light

\footnotetext{
${ }^{45}$ In the sections of the village where northern migrant families lived, there were many smaller homes. This usually reflected the lack of extended family members for most recent migrants. Interestingly, the second- and third-generation migrant families often had constructed large family compounds in the local Akan style.

${ }^{46}$ Frequently families with older villas have added at least one "motel" block to the back or side to house married children, nieces and nephews, or adult siblings.
} 
of the volatility of the market, and not all older cocoa farmers are utterly bereft of financial security. Furthermore, these solidarities will continue to change over time with changes in the life course of the participants. This study begs an important question: what will these young "emperors" do when they grow old and can no longer farm tomatoes? Although difficult to assess at this early stage, there was little evidence of any efforts by youth to accumulate any kind of private savings for an "individually secured retirement."

Second, in Côte d'Ivoire, even though cocoa is still relatively more prosperous, leaving vertical social linkages between the young and old relatively strong, social support networks in general are under strain as a result of economic crisis. Not every elderly parent or uncle in Côte d'Ivoire is well cared for by children or nephews. Even though incentives to look after elderly parents and uncles remain in place, young people often lack the means to follow through. A middle-aged woman emphasized that it was not a lack of volition but rather a lack of means that hindered the care of the elderly: "Because it's difficult, what one wants to give them, one doesn't earn. Because our farm produce isn't bought at a good price, our means are not sufficient to take care of the elderly." 47 Nevertheless, the fact remains that a greater number of Ivoirians than Ghanaians report caring for an elderly person. Furthermore, in Côte $\mathrm{d}$ 'Ivoire this role is more often described in a nurturing and positive way than in Ghana.

\section{CONCLUSION}

This article presents evidence that the dramatic shift away from cocoa to tomatoes as a cash crop in Ghana has redefined the boundaries of solidarity. The declining relative importance of land and the growing need for labor has resulted in new sets of incentives and has consequently reshaped social support networks in two important ways. First, Ghanaians in this region tend to give social support to persons with whom they share a wider range of social ties than do Ivoirians. Second, social ties in Ghana appear to be denser among family, friends, and others of the same age cohort than those in Côte d'Ivoire. We have seen how these more diversified and horizontally oriented social networks weaken the basis for long-term reciprocity between the young and old.

By contrast, with the continued emphasis on cocoa production in Côte d'Ivoire inter-generational solidarity between the young and the old remains relatively strong. Ivoirians tend to give to a more concentrated group of social ties, and this support appears to link rather than segregate different age groups. While the economic crisis obviously constrains the support given to the elderly in both countries, the study demonstrates how different systems of economic production can alter the dynamics of elderly care, in this case providing incentives for elderly care in Côte d'Ivoire and disincentives for the same in Ghana.

\footnotetext{
47 Survey interview (anonymous) by author, Opanin, Côte d'Ivoire.
}

So, what are the broader implications of these findings? First, state policies do actually influence African societies. We have seen how even state policies outside of the social sector, such as in agriculture, can have profound, indirect impacts on social relations and social support networks by shaping local systems of production. Berry (1993) makes a valuable contribution by demonstrating the different ways in which various types of farmers have gained access to productive resources through social networks, but she underestimates the potentially transformative effects of colonial and post-colonial state power. In the present case we find that the history of more exploitative agricultural policies towards cocoa in Ghana has facilitated a shift to tomato production, overturning prior local hierarchies of social, economic, and political power and spurring a redefinition of the boundaries of community. Meanwhile, these boundaries have so far proved relatively "sticky" in Côte d'Ivoire, where cocoa production continues to prosper based on the continuation of more supportive state policies toward permanent tree crops. The renegotiation of social networks is occurring in fits and starts, not in the constant, ongoing manner that Berry describes. We have also seen that these social-structural changes are not seamless or painless; the fluidity of social institutions comes at a cost because at new junctures some actors are more or less able to take advantage of opportunities created by state policies. Finally, state and donor policies based on the assumption of a more comprehensive "informal" social safety net need to be informed by particular local social contexts at particular points in time, and redesigned accordingly.

This study has also highlighted the risks and pain involved in renegotiating economic livelihoods. Though responding to the same price signals, some Ghanaian tomato farmers have rapidly become wealthy while others have lost their shirts. Consequently, as more farmers in the area try to win the same tomato "lottery," prices fall further. Hence, the long-term sustainability of expanded tomato production is doubtful unless the tomatoes can be canned, or transported "fresh" to international markets. ${ }^{48}$ To see these local shifts in economic production as simply responses by rational African farmers to changing prices prevents us from comprehending the real desperation felt by many farmers, both young and old, as they abandon the relatively more stable, albeit less profitable, production of cocoa. Such a perspective also occludes broader political factors-market prices and incentives are not simply generated by a "neutral" market, but by a market constructed, regulated, and re-regulated by the state in Ghana and in Côte d'Ivoire.

With these factors in mind, we can predict that Ghanaian farmers will be re-

48 Tomato canning has been attempted in the past but with little success to date. This is ironic given the number of imported tomato paste cans that are purchased and used to cook local dishes. One obstacle to cost-effective local canning is that only extremely small quantities are desired for purchase in the local market due to the liquidity constraints of most households (Gracia Clark, personal communication, Nov. 2003). 
luctant to make long-term investments in agriculture. This hypothesis is supported by the fact that Ghanaian farmers do not appear to be investing in irrigation systems, despite the enormous inputs of labor required to water tomato plants. Furthermore, even though water is becoming relatively scarce, there is no evidence of local-level initiatives to regulate its access and use. This is of particular interest since irrigation problems were found to have direct, negative implications for the social support of children and the elderly in Ghana. Last$1 \mathrm{y}$, and perhaps more controversially, the article suggests that rationality does not apply only to farming systems, to choices regarding cash crop production, but also to the construction of social networks. Given divergent sets of incentives, Ghanaians and Ivoirians prioritized different social ties in different ways.

This article raises questions concerning other implications of the divergent structure of social networks. It reveals that the more diversified and horizontally oriented networks in Ghana ceased to effectively link the young and the old, and strained inter-generational solidarity. While this is clearly bad news for the long-term social security of the elderly in Ghana, what are the implications for the practice of politics? Most of the attention on the role of youth in Africa has focused on the phenomenon of "child soldiers," but the case presented here suggests the potential for a more positive role for youth, where their participation may integrate political systems rather than disintegrate them. In Ghana, social networks appear to connect individuals from different extended families, ethnic backgrounds, genders, and classes, whereas in Côte d'Ivoire ties are more concentrated within family systems of the same ethnicity, gender, and class. The more diversified ties of the Ghanaians might foster social ties across a broader range of groups, promoting broader political coalitions and supporting enhanced political participation in decision-making-a sort of grassroots democracy. In Côte d'Ivoire, by contrast, the more concentrated and vertical networks will most likely reinforce social and political exclusion, and hinder political participation and local democratic development.

REFERENCES

Almond, Gabriel A. and James S. Coleman, eds. 1960. The Politics of the Developing Areas. Princeton: Princeton University Press.

Apt, Nana A. 1996. Coping with Old Age in a Changing Africa: Social Change and the Elderly Ghanaian. Avebury: Aldershot.

Bayart, Jean-Francois. 1993. The State in Africa: The Politics of the Belly. New York: Longman Group Publishers.

Benda-Beckmann, F. von, et al., eds. 1988. Between Kinship and the State: Social Security and Law in Developing Countries. Dordrecht: Foris Publications.

Berry, Sara. 1993. No Condition is Permanent: The Social Dynamics of Agrarian Change in Sub-Saharan Africa. Madison: University of Wisconsin Press.

1997. Tomatoes, Land and Hearsay: Property and History in Asante in the Time of Structural Adjustment. World Development 25, 8:1225-41.

Chazan, Naomi. 1988. Patterns of State-Society Incorporation and Disengagement. In, Donald Rothchild and Naomi Chazan, eds., The Precarious Balance: State and Society in Africa. Boulder: Westview Press.
Clark, Gracia. Negotiating Asante Family Survival in Kumasi, Ghana. Africa 69, 1: 66-

Demery, Lionel. 1994. Côte d'Ivoire: Fettered Adjustment. In, Ishrat Husain and Rashid Faruqee, eds., Adjustment in Africa: Lessons from Country Case Studies. Washington, D.C.: World Bank.

Engels, Frederick. 1972. The Origin of the Family, Private Property and the State. New York: International Publishers.

Esping-Anderson, Gosta. 1990. The Three Worlds of Welfare Capitalism. Princeton: Princeton University Press.

Frimpong-Ansah, A. 1991. The Vampire State in Africa: The Political Economy of Decline in Ghana. London: James Currey.

Gupta, Akhil. 1998. Postcolonial Developments: Agriculture in the Making of Modern India. Durham: Duke University Press.

Gyimah-Boadi, E. 1995. Ghana: Adjustment, State Rehabilitation and Democratization In, Thandika Mkandawire and Adebayo Olukoshi, eds., Between Liberalisation and Oppression: The Politics of Structural Adjustment in Africa. Dakar: CODESRIA.

Herbst, Jeffrey. 2000. States and Power in Africa: Comparative Lessons in Authority and Control. Princeton: Princeton University Press.

Hirtz, Frank. 1995. Managing Insecurity: State Social Policy and Family Networks in the Rural Philippines. Saarbrucken: Verlag fur Enwicklungspolitik Breitenbach $\mathrm{GmbH}$.

Hyden, Goran. 1980. Beyond Ujaama in Tanzania: Underdevelopment and an Uncaptured Peasantry. Berkeley: University of California Press.

Leechor, Chad. 1994. Ghana: Frontrunner in Adjustment. In, Ishrat Husain and Rashid Faruqee, eds., Adjustment in Africa: Lessons from Country Case Studies. Washington, D.C.: World Bank.

Lerner, Daniel. 1958. The Passing of Traditional Society: Modernizing the Middle East. Glencoe: Free Press.

Marx, Karl. 1978. The German Ideology: Part I. In, Robert C. Tucker, ed., The MarkEngels Reader, 2d ed. New York: W. W. Norton \& Co.

Mbembe, Achille. 2001. On the Postcolony. Berkeley: University of California Press.

McMillan, Margaret and William Masters. 1999. "A Political Economy Model of Agricultural Taxation, R\&D, and Growth in Africa." Discussion Paper 99-03, Department of Economics. Medford: Tufts University.

Midgley, James and Martin Tracy, eds. 1996. Challenges to Social Security: An International Exploration. Westport, Conn.: Auburn House.

Migdal, Joel. 2001. State in Society: Studying How States and Societies Transform and Constitute One Another. New York: Cambridge University Press.

Morris MacLean, Lauren. 2002. Constructing a Social Safety Net in Africa: An Institutionalist Analysis of Colonial Rule and State Social Policies in Ghana and Cote d'Ivoire. Studies in Comparative International Development 37, 3:64-90.

Pierson, Paul. 1996. The New Politics of the Welfare State. World Politics 48:143-79. Reno, William. 1998. Warlord Politics and African States. Boulder: Lynne Rienner Publishers.I

Rodrik, Dani. 1997. Has Globalization Gone Too Far? Washington, D.C.: Institute for International Economics.

Sandbrook, Richard. 1985. The Politics of Africa's Economic Stagnation. New York: Cambridge University Press.

Schlesinger, Mark and Vincent L. Hutchings. 2002. "Affiliation, Collective Identification and Public Policy: Medicare Privatization and Elders' Attitudes toward Federal Involvement in Medical Care." Paper presented at Robert Wood Johnson Foundation Scholars in Health Policy Research Annual Meeting, Aspen, Colo. 


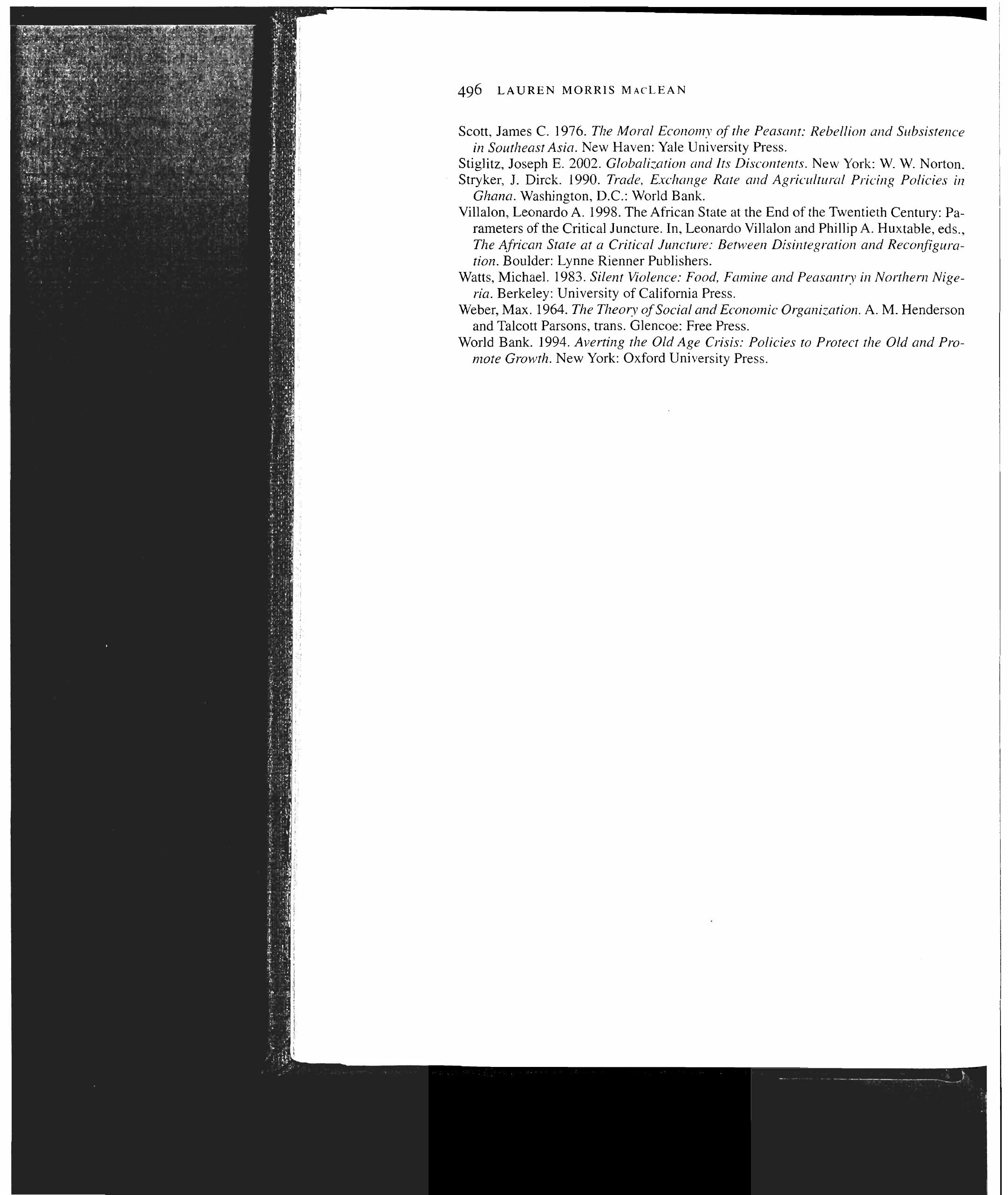

